\title{
Easy and efficient chemical sterilization of the culture medium for in vitro growth of gerbera using chlorine dioxide $\left(\mathrm{ClO}_{2}\right)^{(1)}$
}

\author{
JEAN CARLOS CARDOSO(2)* and ANA CAROLINA PETIT IMTHURN ${ }^{(3)}$
}

\begin{abstract}
Micropropagation techniques changed the production of clonal plantlets in the world. However, the high costs of micropropagated plantlets continue as the main constraint for the expansion of the technique. This paper aimed to test the use of the chemical sterilization of culture medium using chlorine dioxide $\left(\mathrm{ClO}_{2}\right)$ for in vitro cultivation of gerbera. There was used gerbera in vitro shoots in the stage of rooting for these experiments, using $0.0035 \%, 0.0070 \%$ and $0.0105 \%$ of chlorine dioxide in the culture medium. Also, peracetic acid was tested previously for sterilization, but resulted in microbial contamination. Chemical sterilization of the culture medium was successfully using $\mathrm{ClO}_{2}$ at $0.0035 \%$ to $0.0105 \%$ (100\% decontamination) at rooting and elongation stage of gerbera with production of plantlets with similar (number of leaves, total and root fresh weight) or higher quality (mainly aerial part) at rooting/elongation stage, compared with autoclaved culture medium. The increase of concentration of $\mathrm{ClO}_{2}$ also resulted in increasing of height and fresh weight of aerial part of gerberas. The $\mathrm{ClO}_{2}$ could replace the autoclaving with production of sterilized culture medium without phytotoxic problems to gerbera in vitro cultivation.
\end{abstract}

Keywords: Gerbera jamesonii, micropropagation, sterilization methods, cost reduction, chemical alterations, phytotoxicity.

\section{RESUMO}

Esterilização química do meio de cultura para o cultivo in vitro de gérbera utilizando dióxido de cloro $\left(\mathrm{ClO}_{2}\right)$ As técnicas de micropropagação de plantas mudaram a produção de mudas clonais no mundo. Entretanto, os altos custos das mudas micropropagadas ainda continuam sendo o maior desafio para a expansão dessa tecnologia. O objetivo de realizar esse trabalho foi o de usar a esterilização química do meio de cultura utilizando o dióxido de cloro $\left(\mathrm{ClO}_{2}\right)$ para o cultivo in vitro de gerbera. Para isso foram utilizadas, nesse experimento, gérberas cultivadas in vitro no estágio de enraizamento, utilizando o dióxido de cloro nas concentrações de $0,0035 \%, 0,0070 \%$ and $0,0105 \%$ para a esterilização química do meio de cultura. Também, um produto a base de ácido peracético foi testado previamente, mas resultou em contaminação microbiana dos meios de cultura. A esterilização química do meio de cultura ocorreu de forma efetiva utilizando o $\mathrm{ClO}_{2}$ entre $0,0035 \%$ e $0,0105 \%$ (100\% descontaminação), com a obtenção de plantas de gérbera com qualidade similar (número de folhas, massa total e de raízes) ou superior (principalmente a parte aérea) na fase de enraizamento/alongamento, comparado aquelas obtidas em meio autoclavado. $\mathrm{O}$ aumento da concentração de $\mathrm{ClO}_{2}$ resultou em incremento da altura e massa fresca da parte aérea de gérberas. $\mathrm{O}$ uso do $\mathrm{ClO}_{2}$ pode substituir o método de autoclavagem, com a produção de meios de cultura livre de contaminantes e sem efeitos fitotóxicos as gérberas cultivadas in vitro. Palavras-chave: Gerbera jamesonii, micropropagação, métodos de esterilização, redução de custos, alterações químicas, fitotoxicidade.

\section{INTRODUCTION}

Production of in vitro plantlets by micropropagation represents, actually, one of the most important applied technologies, which increase clonal propagation capacity and help breeders for accelerating conventional breeding programs or using biotechnological tools. However, the high costs of micropropagated plantlets resulted in limited application of this technology only for a species with high difficulties of propagation by other conventional methods and for species with important problems of systemic diseases (CARDOSO et al., 2018).
Gerbera (Gerbera jamesonii) is one of most important ornamental species for cut-flower production, in which conventional propagation is difficulty by the low rate of propagation and the increase of systemic diseases in plants obtained from these methods. In this way, the micropropagation is the only method that reliable the production of commercial clonal plantlets without phytosanitary problems (CARDOSO and TEIXEIRA DA SILVA, 2013).

The electrical energy is mainly used in plant tissue culture labs for control temperature and light in growth room, and for autoclaving the culture medium, which

DOI: http://dx.doi.org/10.14295/oh.v24i3.1222

(1) Received in 18/05/2018 and accepted in 04/07/2018

(2) Universidade Federal de São Carlos, Centro de Ciências Agrárias, Departamento de Biotecnologia, Produção Vegetal e Animal, Laboratório de Fisologia de Plantas e Cultura de Tecidos, Araras-SP, Brazil. *Corresponding author: jeancardosoctv@gmail.com

${ }^{(3)}$ Monsanto do Brazil, South America Knowledge Transfer Coordinator, South America Agronomy, Technology Development, São Paulo-SP, Brazil.

Licensed by CC BY 4.0 
represents actually $20-25 \%$ of costs of micropropagated plantlets (CARDOSO and TEIXEIRA DA SILVA, 2013; CHEN, 2016). The culture medium is commonly autoclaved $\left(120{ }^{\circ} \mathrm{C}\right.$ and $1 \mathrm{kgf} \mathrm{cm}^{-2}$ for 20-30 $\mathrm{min}$ ) for in vitro plant cultivation, but this technique delays the culture medium preparation and increases the cost of micropropagated plantlets (CARDOSO, 2009; TEIXEIRA et al., 2008). The autoclaving could also result in production of toxic compounds for plant cultivation, such as 5-(hydroxymethyl)-2-furaldehyde and phenolics (WANG and HSIAO, 1995).

The chemical sterilization of the culture medium is an alternative to autoclaving and represents the most easyand viable technique for microbial decontamination of the culture medium, besides autoclaving. However, the use of sterilizing chemicals could also result in no complete sterilization of culture medium and/or phytotoxicity for plantlet cultivation that reduces the efficiency of the propagation (TIWARI et al., 2012, VARGAS et al., 2016). Then, potential sterilizing chemicals needs be tested both for sterilization efficiency and to evaluate it phytotoxicity for plant cultivation, before the use in large-scale systems of micropropagation.

Chlorine based chemicals as $\mathrm{ClO}_{2}$ (CARDOSO, 2009) and $\mathrm{NaOCl}$ (TEIXEIRA et al., 2006) was proved it efficiency for use on in vitro cultivation of plantlets. $\mathrm{ClO}_{2}$ acts destroying cell membrane and oxidizing intracellular components of microorganisms (HUANG et al., 1997). Interestingly, autoclaving continues as the main sterilization method in tissue culture lab conditions because the long historical uses in plant tissue culture labs with excellent repeatability both for it successfully microorganism sterilization and low phytotoxicity.

Together, there are a high potential to test and uses of chemicals disposable in the market as disinfectant for chemical sterilization of culture medium using conventional micropropagation (agar-media), but also for bioreactor systems (liquid media with temporary-immersion systems), aiming the selection of a high efficient product for microbial sterilization and that not causes phytotoxicity effects on cultivated in vitro shoots and plantlets. The replacement of autoclaving by chemical sterilization could also result in cost reduction of micropropagated plantlets. The peracetic acid is a bleaching solution using commonly for fruit sanitation with similar effects of sodium hypochlorite (WALTER et al., 2009) and the dioxide chlorine have large applications as make water safe to drink, including plant cultivation without phytotoxicity reported problems (CARRILLO et al., 1996).

The aim of this paper was to test two types of chemicals, chlorine dioxide and peracetic acid, compared with autoclaving, and it efficiency in sterilization of semi-solid culture medium and for in vitro cultivation of gerbera in stage of rooting and elongation.

\section{MATERIAL AND METHODS}

Micropropagated shoots of gerbera cv. Basic, with rose inflorescences, previous cultured in multiplication culture medium, were used as explants for the experiment.
The culture medium of the actual experiment was used at rooting phase of gerbera micropropagation and consisted of Murashige and Skoog (1962) with the half of macronutrients (MS 1/2), $30 \mathrm{~g} \mathrm{~L}^{-1}$ of sucrose, $0.1 \mathrm{~g} \mathrm{~L}^{-1}$ of myo-inositol and $0.1 \mathrm{mg} \mathrm{L}^{-1}$ of indol-butyric acid (IBA).

The $\mathrm{pH}$ of the autoclaved $\left(121{ }^{\circ} \mathrm{C} ; 1 \mathrm{kgf} \mathrm{cm}^{-2} ; 20\right.$ min) control culture medium was adjusted for 5.8 before the addition of $6 \mathrm{~g} \mathrm{~L}^{-1}$ agar, and after autoclaving the $\mathrm{pH}$ was reduced for 5.4. The $\mathrm{pH}$ of chemical sterilized culture media with $\mathrm{ClO}_{2}$ were adjusted for 5.8 to 6.0 using chloridric acid $(\mathrm{HCl})$ at $0.1 \mathrm{~N}$ (Table 1), depending on concentration and were realized after the addition of $\mathrm{ClO}_{2}$ at different concentrations $(0.0035 \%, 0.0070 \%$ and $0.0105 \%$ ) (CARDOSO, 2009) mainly because addition of chemical (DioxiPlus ${ }^{\circledR}$, Indaiatuba, Brazil) increase the $\mathrm{pH}$ value of the culture medium for 7.0 to 7.5 in these concentrations. At contrary, addition of the peracetic acid (Proxitane $\AA$, Cotia, Brazil) at 1.0, 2.0 and $3.0 \mathrm{ml} \mathrm{L}^{-1}$ reduces drastically the $\mathrm{pH}$ of the culture medium to 3.5 to 4.5 and the $\mathrm{pH}$ was adjusted for 5.8 using potassium hydroxide $(\mathrm{KOH})$ at $0.5 \mathrm{~N}$.

After adjusting the $\mathrm{pH}$, electrical conductivity (EC) of each culture media was also measured before shoot inoculation (initial EC) (Table 1). The $\mathrm{pH}$ of the control was realized after culture medium autoclaving. The $\mathrm{pH}$ and the EC of the culture media were also measured after 28-d of gerbera in vitro cultivation (final $\mathrm{pH}$ and $\mathrm{EC}$ ).

Around 10 repetitions (flasks) containing culture medium were maintained for $28-\mathrm{d}$ in growth room at $25^{\circ} \mathrm{C}$ without inoculation of gerbera, for previous evaluation of sterilization efficiency of peracetic acid, chlorine dioxide and autoclaved culture medium. In this essay, a control with none treatment of sterilization was used. This essay was evaluated by the contamination percentage of flasks. Also, bacterial or fungi contamination were quantified according each treatment.

The experiment with in vitro shoots of gerberas was realized only with $100 \%$ decontaminated treatments observed in the previous essay.

Individualized shoots with $2.6 \pm 0.2 \mathrm{~cm}$ in length and containing two leaves and none roots were used as explants. Each flask (repetition) with $200 \mathrm{ml}$ capacity and $35 \mathrm{ml}$ of the culture medium contains four individual shoots, and five flasks for each treatment were used. The experiments were realized in completely randomized design and were repeated twice.

The plantlet development was evaluated by the height of plantlets, number of leaves and roots and fresh weight (total, aerial part and roots) with 28-d after in vitro cultivation in $25 \pm 1{ }^{\circ} \mathrm{C}$, 16 -h photoperiod with white

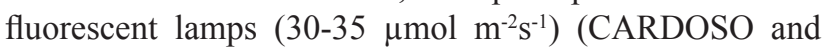
TEIXEIRA DA SILVA, 2013).

The means were submitted to Analysis of Variance (ANOVA) followed by the mean comparison by Duncan's Test at $5 \%$ probability.

\section{RESULTS AND DISCUSSION}

The autoclaving treatment resulted in expected $100 \%$ sterilization, without common contamination caused by 
fungi or bacteria microorganisms in culture medium. Also, the control without any treatment of sterilization showed $60 \%$ of contamination by microorganisms in the first 7-days of incubation after the culture medium preparation and at 28 days resulted in $100 \%$ of contaminated flasks with culture medium (Table 1).

Table 1. Contamination percentages of culture medium using autoclaving or chemical sterilization with different products for sterilization.

\begin{tabular}{|c|c|c|c|c|c|c|}
\hline \multirow[t]{2}{*}{ Treatments } & \multicolumn{4}{|c|}{ Contamination percentage (days after sterilization) } & \multicolumn{2}{|c|}{ Type of contamination } \\
\hline & 7 & 14 & 21 & 28 & Fungi & Bacteria \\
\hline Control & 60 & 70 & 80 & 100 & 80 & 20 \\
\hline Autoclaved & 0 & 0 & 0 & 0 & 0 & 0 \\
\hline $\mathrm{ClO}_{2}[0.0035 \%]$ & 0 & 0 & 0 & 0 & 0 & 0 \\
\hline $\mathrm{ClO}_{2}[0.007 \%]$ & 0 & 0 & 0 & 0 & 0 & 0 \\
\hline $\mathrm{ClO}_{2}[0.0105 \%]$ & 0 & 0 & 0 & 0 & 0 & 0 \\
\hline $\mathrm{Pa}\left[1 \mathrm{~mL} \mathrm{~L}^{-1}\right]$ & 50 & 70 & 80 & 80 & 80 & 0 \\
\hline $\mathrm{Pa}\left[2 \mathrm{~mL} \mathrm{~L}^{-1}\right]$ & 30 & 60 & 60 & 60 & 60 & 0 \\
\hline $\mathrm{Pa}\left[3 \mathrm{~mL} \mathrm{~L}^{-1}\right]$ & 0 & 20 & 20 & 20 & 20 & 0 \\
\hline
\end{tabular}

$\mathrm{ClO}_{2}$ - liquid stabilized chlorine dioxide at 7\% concentration (Dioxiplus ${ }^{\circledR}$, Dioxide, Indaiatuba-SP, Brazil); Pa - Peracetic Acid (0.25\%), peroxide

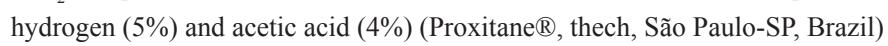

Either in control or with sterilization treatments that presented contamination, $80 \%$ to $100 \%$ of the total contaminated flasks were caused by fungi (Table 1), observed by the growth of different type of mycelia.

The chemical sterilization with peracetic acid added to the culture medium reduced but not complete eliminate the microorganism contamination, independently of the concentration used. The most effective concentration of peracetic acid was $3 \mathrm{ml} \mathrm{L}^{-1}$, which reduced the total percentage of contaminated flasks from 100\% (control) to $20 \%$ (Table 1). Higher concentrations could be resulted in $100 \%$ decontamination, but not were tested in this experiment, mainly due the excessive acidification of the culture medium.

As observed, the use of chemical sterilization with liquid stabilized chlorine dioxide $\left(\mathrm{ClO}_{2}\right)$ at $0.0035 \%$ to $0.0105 \%$ resulted in $100 \%$ of decontamination flasks, since after 28-days of incubation, the same time required for gerbera transplantation to new culture medium (Table 2). Although the mode of action of chlorine in microorganism is not complete elucidated, the $\mathrm{ClO}_{2}$ acts destroying cell membrane and oxidizing intracellular components of microorganisms (HUANG et al. 1997). In Anthurium andraeanum there was possible to observe the complete decontamination of the culture medium after 90 -d of in vitro cultivation of shoots, and the transplantation of these shoots to autoclaved rooting medium not resulted in any contamination (CARDOSO et al., 2009), showing the real effect of chlorine dioxide as sterilizing. Also, in the same work with $A$. andraeanum, the complete sterilization of the culture medium was not obtained using peracetic acid, with $100 \%$ of contaminated flasks after $21-\mathrm{d}$ of in vitro cultivation of Anthurium (CARDOSO et al., 2009).

The results obtained in the first experiment, with different methods for sterilization, lead to conduct the experiment with in vitro development of gerbera only with different concentrations of chlorine dioxide compared to autoclaved culture medium.

In this second experiment, with chemical sterilization using different concentrations of chlorine dioxide, there was observed the total sterilization of culture medium, with any type of contamination or microorganism signals in the culture medium contained plantlets of gerbera. Also, there was not observed any signals of phytotoxicity caused in gerbera plantlets by the addition of chlorine dioxide to the culture medium, such as phenol production and liberation in the culture medium, yellowing of leaves, absence or necrosis of roots, or another signals that could be detected visually. The plantlets obtained with culture medium chemical sterilized have similar leaf morphology and green coloration intensity compared to obtained in conventional autoclaved culture medium (Figure 1). 


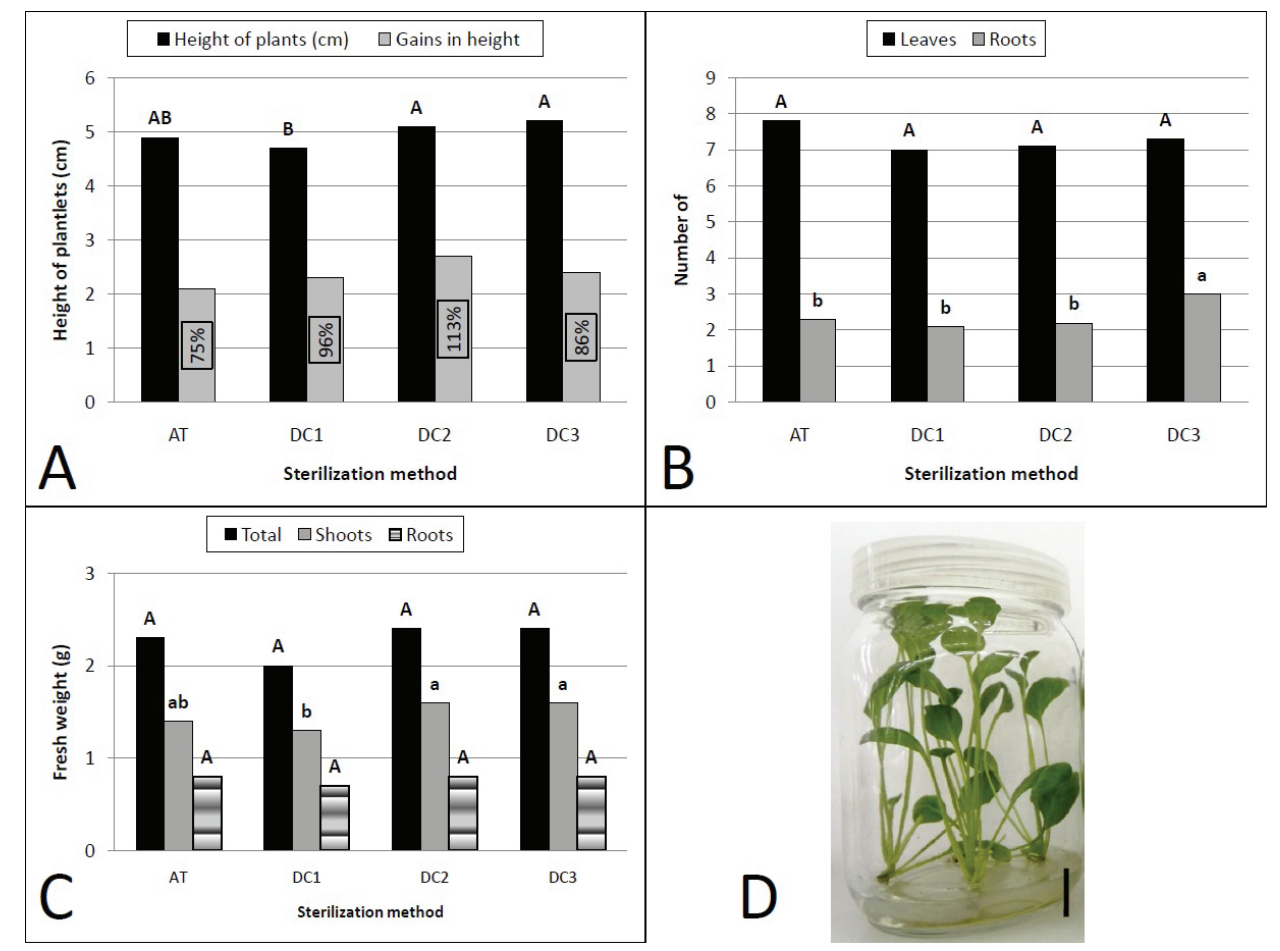

Figure 1. In vitro development of gerbera cv. Basic in autoclaved (AT) and chemical sterilized culture media with chlorine dioxide $\left(\mathrm{ClO}_{2}\right)$ at 0.0035 (DC1), 0.0070 (DC2) and 0.0105\% (DC3): (A) Total Height (cm) and gains in height; (B) Number of leaves and roots; (C) Total, shoot and root fresh weight (g); (D) Morphological characteristics of plantlets of gerbera cv. Basic cultivated for 28 - $\mathrm{d}$ in culture medium sterilized with $0.0070 \%$ of $\mathrm{ClO}_{2}$ (chemical sterilized). Columns with the same letters for each evaluated characteristic not differs at 5\% probability using Duncan's average test. Bar: $1.0 \mathrm{~cm}$

Also, the shoots of gerbera presented good development using chemical sterilization, compared to autoclaved culture medium. The chemical sterilization of the culture medium resulted in similar height compared with autoclaved culture medium, with gains in height ranged from $86 \%$ and $113 \%$ after 28-d of in vitro cultivation (Figure 1). These gains represents the differences in height between the initial height of inoculated gerbera shoots and the height measured after 28-d of in vitro cultivation.

Also, the number of leaves and fresh weight of aerial part and roots were similar to observed with autoclaved culture medium (Figure 1). Only the number of roots presented significant difference with highest number of roots (3.0 plant $\left.^{-1}\right)$ at $0.0105 \%$ of chlorine dioxide, with $30 \%$ increasing, compared with autoclaved $\left(2.3\right.$ plant $\left.^{-1}\right)$ culture medium (Figure 1).

The results obtained could be partially explained by the chemical characteristics of the culture medium that presented differences among the autoclaved and chlorine dioxide chemical sterilized. As example, the initial $\mathrm{pH}$ of the chemical sterilized culture medium maintained similar or few higher $\mathrm{pH}$, compared to the first adjusted (near from 5.8), ranging from $5.85(0.0035 \%)$ to 5.97 $(0.0105 \%)$, while the $\mathrm{pH}$ of autoclaved culture medium reduced from 5.8 (before) to 5.4 (after the physical treatment) (Table 2).

Table 2. $\mathrm{pH}$ and electrical conductivity (EC) of the culture medium before and after 28-d of in vitro cultivation of gerbera

\begin{tabular}{|c|c|c|c|c|}
\hline Culture & \multicolumn{4}{|c|}{ Chlorine dioxide } \\
\hline \multirow[t]{2}{*}{ Medium } & Autoclaved & $0.0035 \%$ & $0.0070 \%$ & $0.0105 \%$ \\
\hline & \multicolumn{4}{|c|}{ pH } \\
\hline Initial pH & 5.40 & 5.85 & 5.98 & 5.97 \\
\hline Final pH & 4.04 & 3.89 & 3.90 & 3.87 \\
\hline \multirow[t]{2}{*}{$\Delta \mathrm{pH}$} & -1.36 & -1.96 & -2.08 & -2.10 \\
\hline & \multicolumn{4}{|c|}{$C E\left(d S ~ m^{-1}\right)$} \\
\hline Initial EC & 2.40 & 2.30 & 2.20 & 2.40 \\
\hline Final EC & 1.72 & 1.49 & 1.67 & 1.64 \\
\hline$\triangle \mathrm{CE}$ & -0.68 & -0.81 & -0.53 & -0.76 \\
\hline
\end{tabular}


Interestingly, although the final $\mathrm{pH}$ (after 28-d of gerbera cultivation) was reduced for similar values among autoclaved or chemical sterilized treatments, ranging from $3.87\left(0.0105 \% \mathrm{ClO}_{2}\right)$ to 4.04 (autoclaved), a significative difference in $\Delta \mathrm{pH}$ were observed among autoclaved (-1.36) and chemical sterilized culture medium $(-1.96$ to -2.1$)$. At the same time, the $\triangle \mathrm{EC}$ also ranged from -0.53 to -0.81 with chemical sterilization and -0.68 with autoclaved culture medium. The EC (electrical conductivity) of the MS culture medium with half concentration of macronutrients (MS 1/2) with sucrose at $3 \%$, before the sterilization procedures, was 2.2-2.4 $\mathrm{dS} \mathrm{m}^{-1}$ (Table 2).

Based on the observations of reduction of EC (direct correlated with nutrient consumption by the plantlets) to $1.49\left(0.0035 \% \mathrm{ClO}_{2}\right)$ and 1.72 (autoclaved), there was concluded that the most chemical limitation of the culture medium for in vitro gerbera plantlet development was the $\mathrm{pH}$, because the stabilization of final $\mathrm{pH}$ for all treatments was around 3.9-4.0, independently of the reduction of
EC value. Probably, this reduction of $\mathrm{pH}$ also affects the nutrient uptake or it availability to in vitro plantlets affecting the plantlets development, because the EC of 1.51.7 (observed at the end of in vitro gerbera cultivation) is considered a good reference for production of adult plants of gerbera under fertigation using semi-hydroponics system (LUDWIG et al., 2010). This observations lead to a conclusion of several lost of nutrients added to the culture medium that not participate of in vitro plantlet development processes due to $\mathrm{pH}$ reduction in culture medium.

Cardoso and Silva (2012) observed that chlorine dioxide at $0.0025 \%$ could be used for chemical sterilization of the culture medium in the in vitro cultivation of gerbera cv. AL101, and also observed similar development of shoots or plantlets when compared with autoclaved culture medium.

Labor and electrical energy together represents more than $80 \%$ of the total cost of each micropropagated plantlet in the lab

Table 3. Costs for preparation of culture medium based on labor and electrical energy costs.

\begin{tabular}{|c|c|c|c|}
\hline \multirow[t]{2}{*}{ Type of costs } & \multirow[t]{2}{*}{ Costs/unit (U\$) } & \multicolumn{2}{|c|}{ Perliter of culture media } \\
\hline & & Quantity & Costs (US) \\
\hline \multicolumn{4}{|c|}{ Autoclaved } \\
\hline Labor & 2.80 / hour & $1 / 4$ hour* & 0.70 \\
\hline Electrical Energy & $0.80 /$ hour & $1 / 4$ hour* & 0.20 \\
\hline Total & & & 0.90 \\
\hline \multicolumn{4}{|c|}{ Chlorine dioxide $\left(\mathrm{ClO}_{2}\right)$} \\
\hline Labor & 2.80 / hour & $1 / 8$ hour & 0.35 \\
\hline Tecsa-Clor $(5 \%)$ & 40.0 / liter & $0.5 \mathrm{ml}(0.0035 \%)$ & 0.01 \\
\hline Total & & & 0.36 \\
\hline
\end{tabular}

*There was considered that the preparation of four liter of culture medium lead around 1-h of labor, using of 75-100 L autoclave capacity and potency of $4000 \mathrm{~W}$.

The replacement of autoclaving by chemical sterilization reduced the use of electrical energy and the labor time for culture medium preparation from $1 / 4$ (autoclaving) to $1 / 8$ hour. The use of chlorine dioxide also reduces the cost with sterilization, especially because the electrical energy for autoclaving have high cost compared with the chemical product used for sterilization (Table 3). The results obtained in actual experiment, based only in these two components showed that the use of chemical sterilization compared with autoclaving, represented a $3.5 \%$ to $5.0 \%$ of cost reduction in individual micropropagated plantlet of gerbera. Brondani et al. (2013) also agree that using of chemical sterilization could result in economy of electrical energy used for autoclaving and time required for culture medium preparation.

The chemical sterilization was used in the replacement of autoclaving using other products, as sodium hypochlorite $(\mathrm{NaClO})$ in the in vitro cultivation of Eucalyptus benthamii (BRONDANI et al., 2013), gerbera cv. Essandre (PAIS et al., 2016), pineapple (TEIXEIRA et al., 2006), among others. Despite the use of other chemical products as hydrogen peroxide (VARGAS et al., 2017) and Plant
Preservative Mixture $\AA$, the chlorine based chemical sterilization as sodium hypochlorite and chlorine dioxide was the most consistent for their low cost, high efficiency in sterilization, and low or no phytotoxycity to different in vitro plant cultivation species at adequate and very low concentrations (CARDOSO, 2009; CARDOSO and SILVA, 2013).

The most common concentrations of $\mathrm{NaClO}$ used were $0.003 \%$ of active chlorine, and the use of higher concentrations lead to phytotoxicity to the cultures, as observed in Eucalyptus in concentrations higher than $0.005 \%$ (BRONDANI et al., 2013) and in Prunus mume at $0.01 \%$ (VARGAS et al. 2016). These last authors also observed that the use of a culture medium chemical sterilized with chlorine dioxide and hydrogen peroxide showed higher percentage of survival $(78,0-80,4 \%)$ and lower contamination rate $(14,7-15,9 \%)$ of nodal segments of Prunus mume, compared with sodium hypochlorite sterilized (45\% survival rate and $45,8 \%$ of contaminated explants). Cardoso and Silva (2012) also not observed phytotoxicity of chlorine dioxide when used for culture medium sterilization until $0.1 \%$ in different stages of 
micropropagation, e.g., establishment, multiplication and rooting/elongation phases. Similarly, in this experiment the use of chlorine dioxide at $0.0035 \%$ to $0.0105 \%$ resulted in best in vitro plantlets of gerbera at rooting/elongation stage.

In micropropagation of sugarcane the concentration of $0.1 \%$ of $\mathrm{NaClO}$ resulted in best treatment for chemical sterilization, with good microbial decontamination (96\%) and normally grown (TIWARI et al., 2012). However, the use of $\mathrm{NaClO}$ depends of the previous treatment of bottles and caps with sodium hypochlorite solution at $0.1 \%$ for 10 min (TEIXEIRA et al., 2008; TIWARI et al., 2012). Using $\mathrm{ClO}_{2}$ there was reported no additional treatments for using chemical sterilization and the flasks used have had the same type of washing in all treatments, only with water and detergent, before sterilization procedures.

The chlorine dioxide also proved is efficient for in vitro growth of Anthurium andraeanum (CARDOSO, 2009). This author was observed that the use of chlorine dioxide resulted in $100 \%$ of sterilization of culture medium with no signals of phytotoxicity until the concentration of $0.010 \%$ of $\mathrm{ClO}_{2}$, while the use of peracetic acid at the same concentration not sterilized the culture medium. The use of $0.05 \%$ of $\mathrm{ClO}_{2}$ also resulted in increases in the leaf number and diameter (CARDOSO, 2009).

Chemical sterilization represents nowadays an interesting alternative for culture medium sterilization, but in most of micropropagation laboratories autoclaving is considered the most security way for culture medium sterilization, main because the long repeatability of results and that avoid any type of microorganism resistance. However, the use of chemical sterilization with chlorine products, as chlorine dioxide, also represents an important tool to be use in plant tissue culture labs for production of thousands of plantlets, and represents one way to reduction costs of micropropagated plantlets, one of the challenges of micropropagation techniques for this century (CARDOSO et al. 2018). Studies with chemical sterilization of also liquid culture media for temporary immersion bioreactor systems needs be realized to evaluate the use and efficiency of chlorine dioxide also for this system, actually used for large-scale micropropagation of plantlets by tissue culture.

\section{CONCLUSIONS}

The use of chlorine dioxide at $0.0035 \%$ to $0.0105 \%$ for chemical sterilization of the culture medium $(100 \%$ decontamination) and to produces of in vitro plantlets is highly effective and replaced autoclaving methods conventionally used for gerbera micropropagation.

\section{ACKNOWLEDGEMENTS}

J.C.C. thanks to CNPQ for the process 304174/2015-7. J.C.C. and A.C.P.I. thanks to Uniplant Co. for infrastructural support.

\section{AUTHORS CONTRIBUTIONS}

J.C.C. (D) 0000-0001-6578-1723: contributes with main idea, experimental design and writing and editing of the paper. A.C.P.I. 0000-0003-4116-5429: contributes with execution of the experiment, data collection and analysis of the experiments, and revision of the paper.

\section{REFERENCES}

BRONDANI, G.E.; DE OLIVEIRA, L.S.; BERGONCI, T.; BRONDANI, A.E.; FRANÇA, F.A.M.; DA SILVA, A.L.L.; GONCALVES, A.N. Chemical sterilization of culture medium: a low cost alternative to in vitro establishment of plants. Scientia Forestalis, v.41, n.98, p.257-264, 2013.

CARDOSO, J.C. Chemical sterilization of culture medium for anthurium in vitro culture. Pesquisa Agropecuaria Brasileira, v.44, n.7, p.785-788, 2009.

CARDOSO, J.C.; GERALD, L.T.S.; SILVA, J.A.T Micropropagation in the Twenty-First Century. In: LOYOLA-VARGAS, V.; OCHOA-ALEJO, N. (ed.). Plant Cell Culture Protocols 1815. Switzerland: Springer Science+Business Media, 2018. p.17-46

CARDOSO, J.C.; TEIXEIRA DA SILVA, J.A. Micropropagation of gerbera using chlorine dioxide $\left(\mathrm{ClO}_{2}\right)$ to sterilize the culture medium. In Vitro Cellular \& Developmental Biology - Plant, v.48, n.3, p.362-368, 2012.

CARDOSO, J.C.; SILVA, J.A.T Micropropagation of gerbera. Biotechnology Advances, v.31, n.8, p.1344-1357, 2013.

CARRILLO, A.; PUENTE, M.E.; BASHAN, Y. Application of diluted chlorine dioxide to radish and lettuce nurseries insignificantly reduced plant development. Ecotoxicollogy Environmental Safety, v.35, n.1, p.57-66, 1996.

CHEN, C. Cost analysis of plant micropropagation of Phalaenopsis. Plant Cell Tissue and Organ Culture, v.126, n.1, p.167-175, 2016.

HUANG, J.; WANG, L.; REN, N.; MA, F.; MA, J. Disinfection effect of chlorine dioxide on bacteria in water. Water Research, v.31, n.3, p.607-613, 1997.

LUDWIG, F.; FERNANDES, D.M.; MOTA, P.R.D.; VILLAS BÔAS, R.L. Growth and production of gerbera fertigated with nutrient solution. Horticultura Brasileira, v.28, n.4, p.424-429, 2010. 
PAIS, A.K.; SILVA, A.P.; SOUZA, J.C.; TEIXEIRA, S.L.; RIBEIRO, J.M.; PEIXOTO, A.R.; PAZ, C.D. Sodium hypochlorite sterilization of culture medium in micropropagation of Gerbera hybrid cv. Essandre. African Journal of Biotechnology, v.15, n.36, p.1995-1998, 2016.

TEIXEIRA, S.L.; RIBEIRO, J.M.; TEIXEIRA, M.T. Influence of $\mathrm{NaClO}$ on nutrient medium sterilization and on pineapple (Ananas comosus cv. Smooth cayenne) behaviour. Plant Cell Tissue and Organ Culture, v.86, n.3, p.375-378, 2006.

TEIXEIRA, S.L.; RIBEIRO, J.M.; TEIXEIRA, M.T. Use of sodium hypochlorite in sterilization of culture medium for multiplication of Eucalyptus pellita L. Ciência Florestal, v.18, n.2, p.185-191, 2006.

TIWARI, A.K.; TRIPATHI, S.; LAL, M.; MISHRA, S. Screening of some chemical disinfectants for media sterilization during in vitro micropropagation of sugarcane. Sugar Technology, v.14, n.4, p.364-369, 2012.
VARGAS, D.P.; FORMOSO, R.S.; DUTRA, L.F.; NEWTON, A.M.; SANTOS, J.; UENO, B. Chemical sterilization of in vitro culture for peach rootstock. Colloquium Agrarie, v.12, n.1, p.1-6, 2016.

WALTERS, E.H.; NASCIMENTO, M.S.; KUAYE, A.Y. Efficacy of sodium hypochlorite and peracetic acid in sanitizing green coconuts. Letters in Applied Microbiology, v.49, n.3, p.366-371, 2009.

WANG, X.J.; HSIAO, K.C. Sugar degradation during autoclaving: Effects of duration and solution volume on breakdown of glucose. PhysiologiaPlantarum, v.94, n.3, p.415-418, 1995. 